\title{
O EXISTENCIAL DA LIBERDADE: HEGEL E AS PRECONDIÇÕES DA DEMOCRACIA
}

\author{
THE EXISTENTIAL OF FREEDOM: HEGEL AND THE CONDITIONS OF \\ DEMOCRACY
}

KONRAD UTZ

(UFC - Brasil)

\begin{abstract}
Resumo
O artigo tenciona atualizar alguns aspectos fundamentais da Filosofia Prática de Hegel com vistas à discussão atual sobre a democracia. Hegel oferece uma alternativa à compreensão básica do Político nos grandes debates filosóficos atuais. Para ele, a sociedade civil e o estado não são, em primeiro lugar, espaços onde diferentes formas de poder são exercidas, cujas estruturas devem ser debatidas. Antes disso, o Político é o espaço da auto-efetivação de sujeitos na sua auto-compreensão como seres livres. Essa auto-compreensão precisa ser articulada pela filosofia. A discussão das formas de governo e das estruturas das instituições públicas só pode ser iniciada a partir disso. Essa compreensão de si mesmo que determina toda a vivência dos sujeitos ético-políticos é chamada aqui de "existencial da liberdade": um existencial racional, comunitário e intersubjetivo. Este existencial articula-se como amor na família, como honra profissional na sociedade civil, e, finalmente e mais perfeitamente, como patriotismo no estado, i.e., como "patriotismo da liberdade". No final do artigo, algumas consequências concretas dessa interpretação da teoria hegeliana para nossa compreensão da democracia contemporânea são explicadas.
\end{abstract}

Palavras-chave: Hegel, estado, liberdade, democracia, existencial, partiotismo

\begin{abstract}
The article's aim is to explain how some of the fundamental ideas of Hegel's practical philosophy can be fruitful for our actual discussions on democracy. Hegel offers an approach to the comprehension of the political sphere as a whole which is different from the one that dominates actual debates. For him, the main question is not power, its legitimating and its structures. In the first place, the political sphere is the realm of the realization of freedom, that is, of the self-realization of subjects which is guided fundamentally by their self-comprehension as free beings. This is what political philosophy has to articulate first. Forms of government and institutional structures can be discussed only afterwards, parting from a clear conception of what is called here the "Existential of Freedom". This is a rational, communitarian an inter-subjective Existential, which articulates itself as love in the realm of family life, as professional honour in the realm of civil society and as patriotism in the realm of the state - a form of patriotism which, therefore, could justly be called "Patriotism of Freedom". At the end, the article discusses some concrete consequences this interpretation of Hegel bears on our comprehension of modern democracy.
\end{abstract}

Key-words: Hegel, state, freedom, democracy, existential, patriotism.

\section{Filosofia política e a questão do poder}

A filosofia política normalmente é discutida a partir da questão do poder. Quem deve ter poder num estado, como deve exercê-lo e quais são as restrições a tal poder? Essas são algumas das questões fundamentais que marcam os discursos. A questão central, porém, é a da legitimação 
do poder. Essa legitimação pode ser fundamentada de duas maneiras diferentes. A primeira consiste em legitimar o poder a partir de um princípio: existe alguém que é a fonte originária do poder legítimo, i.e. que originalmente tem ou deve ter liberdade política. Desde a Idade Média até o início do século XX muitos defenderam a opinião de que a única fonte do poder legítimo, o único sujeito que tinha liberdade política originária era Deus. Sua onipotência inclui naturalmente a liberdade política na terra também. Portanto, o poder político tentava legitimar-se a partir da vontade de Deus. Hoje em dia quase ninguém aceita mais isso, nem os teólogos modernos. Quase unanimamente nós modernos estamos de acordo que, se existir tal principio de legitimação do poder, só pode ser o do homem individual.

A concepção da Democracia como a única forma legítima de organização do poder é conseqüência direta disso. Ela pode ser concebida de duas maneiras diferentes. Na primeira, ela fundamenta o poder político a partir da liberdade particular dos indivíduos. Essa é a concepção liberal da democracia. Nessa, o estado democrático tem, antes de tudo, a função de respeitar e garantir as liberdades individuais. Na segunda, ela legitima o poder a partir da vontade comunitária dos indivíduos. Essa é a concepção republicana da democracia. Nessa, a democracia tem a função de realizar a "vontade geral", o projeto comum dos indivíduos. São essas as formas principais de legitimação da democracia a partir de um princípio, i.e. a partir de uma liberdade ou de um direito à autodeterminação primária, original.

Uma outra maneira de legitimar o poder político rejeita a existência de tal princípio. Não há critérios normativos últimos e universais para avaliar formas de Estados, dizem os defensores dessa corrente. A única forma de avaliá-los é comparar sua utilidade para depois decidir qual forma de governo funciona melhor. Porém, essa estratégia também não renuncia totalmente a qualquer idéia normativa. Para definir funcionamento e utilidade, é necessário pressupor uma finalidade. Essa, em última instância, só pode ser um bem originário. E aí quase todos os conseqüencialistas ou utilitaristas modernos mais uma vez insistem no indivíduo como ponto de referência último. É o bem-estar, a felicidade ou o contentamento dos indivíduos a que o poder político deve servir. E, outra vez, a maioria dos filósofos conseqüencialistas conclui que a democracia é a melhor forma de estado para garantir um bom funcionamento do governo a serviço do bem individual.

Este reconhecimento do bem particular, i.e. o respeito pela definição individual do bem é muito importante politicamente. Todas as teorias que não mostram este respeito, teorias que determinam o bem não a partir do indivíduo mas a partir de um princípio metafísico, religioso, histórico ou outro têm uma tendência ao totalitarismo. Elas prescrevem ao indivíduo o que deve ser bom para ele, a que fim ele tem que servir. E como elas acham que sabem melhor do que o próprio indivíduo o que é bom para ele, elas se consideram justificadas para subjugar o indivíduo em nome de seu próprio bem. Se o bem for desvinculado do indivíduo, ele pode até justificar, aos olhos de seus defensores, o sacrifício da vida dos próprios cidadãos em prol da utilidade maior. O século XX foi cheio de exemplos disso. Por isso parece muito sábio vincular o princípio da utilidade à 
felicidade individual.

Em ambas as concepções, a fim de legitimar a democracia o indivíduo é o último ponto de referência. Na primeira proposta, o indivíduo tem a função de um princípio originário. Neste caso a idéia da liberdade do individuo é essencial. Na outra proposta, o indivíduo tem a função de uma finalidade última. Neste caso, a igualdade de todos os indivíduos, i.e. o reconhecimento de cada um é essencial. Em ambos os casos a questão do poder é central. O poder legítimo, dizemos nós democratas, origina-se dos indivíduos em comunidade ou da comunidade de indivíduos, i.e. do povo, seja como princípio, seja como finalidade.

\section{A unilateralidade da perspectiva do poder}

Compreender o Político a partir do poder, porém, representa apenas uma das opções disponíveis e, portanto, representa uma opção unilateral, limitada. Hegel opta por uma alternativa. Ele, por sua vez, cai na unilateralidade porque desrespeita aquela perspectiva do Político que é tão natural para nós hoje em dia. Por isso Hegel chega a conclusões que são inaceitáveis para nós hoje, como p.ex. favorecer a monarquia constitucional nos padrões do séc. XIX como forma ideal do Estado. Neste sentido a Filosofia Política Hegeliana certamente não nos fornece as soluções que estamos buscando. Mas, a meu ver, ela pode ser muito útil e frutífera para reavaliar criticamente aquelas soluções e aquele entendimento do Político e da Democracia que parecem tão normais é até inquestionáveis para nós.

Qual é, então, a unilateralidade da compreensão moderna do político e qual seria a alternativa? Se compreendemos o Político a partir da questão do poder, nós implicitamente o compreendemos sob o primado do agir. O que é o poder? Poder, no sentido mais amplo, é a capacidade de um sujeito exercer uma vontade. Se quero derrubar uma árvore, essa capacidade consistiria na força corporal e na aptidão das ferramentas de que preciso para fazê-lo. Neste sentido, o poder é o complemento da liberdade. Eu posso ter a liberdade de derrubar a árvore no sentido de que ela não pertença a uma outra pessoa ou de que não exista uma lei ambiental que proíba isso. Mas a vontade livre só pode realizar-se se ela tem também o poder para isso. Às vezes o conceito de liberdade (plena) é entendido de tal forma que ele também implica o poder. Liberdade, neste sentido, significa que não me falta nada para realizar minha vontade. De qualquer forma, a liberdade é, desta maneira, sempre vinculada ao agir, ao prático.

Num sentido mais estrito, o poder não é qualquer capacidade de agir, mas a capacidade de um sujeito realizar sua vontade através de outros sujeitos. O poder é a capacidade de fazer com que outros sujeitos façam o que eu quero. A questão fundamental do Político é, então, quem manda e quem obedece, quem domina e quem está subordinado. A democracia pode ser vista como a resposta 
ideal a essa pergunta, porque apresenta a solução mais equilibrada. Na democracia, de certa maneira, todos mandam e todos obedecem. E se alguém tem mais poder que outros, ele o tem apenas porque os outros livremente lhe conferiram este poder através de processos democráticos. Mas, desta forma, a compreensão da democracia não sai da dicotomia básica entre domínio e subordinação.

\section{A alternativa Hegeliana}

Qual seria, então, a alternativa que Hegel propõe? A proposta de Hegel é entender o Político não apenas a partir do agir, mas também a partir do conhecer, não somente a partir da prática, mas da teoria, ou, dizendo melhor, a proposta hegeliana consiste em compreender a própria prática a partir do conhecimento. Isso, como eu já disse, representa uma unilateralidade, um desequilíbrio na Filosofia Hegeliana e como tal deve ser criticado. Não obstante, isso serve muito bem para criticar e corrigir o desequilíbrio da noção comum do Político que temos hoje em dia.

Mas como é possível compreender a prática a partir da teoria? Afinal de contas, prática significa interferir na realidade, mudá-la e modificá-la, enquanto teoria, por outro lado, visa exatamente o oposto: no conhecimento deixo as coisas como estão para conhecê-las como estão e não como eu queria que elas estivessem. Na teoria, o sujeito tenta adequar seus pensamentos ao objeto, tenta deixar-se determinar por ele. Na prática, o sujeito tenta adequar seu objeto a suas idéias. Ele tenta determinar o objeto. Ambos os processos são, enquanto tais, processos de alienação. Na teoria, o sujeito se sujeita ao objetivo. Na prática, ele visa dominá-lo. O segundo caso, à primeira vista, não parece tão problemático. Não seria um ganho para o sujeito se ele conseguisse estender seu poder? Não é exatamente este o sentido da liberdade, que eu possa configurar meu mundo ou pelo menos parte dele segundo minha vontade?

Hegel critica tal conceito de liberdade, argumentando que essa jamais pode ser a liberdade verdadeira. Por quê? Se a liberdade consiste em realizar meus pensamentos no objeto, i.e. em meu outro, o resultado de minha prática estará sempre num outro, fora de mim, alheio a mim. Efetivar sua liberdade seria exteriorizar-se, perder-se no outro e, com isso, perder a liberdade cada vez que a realiza. O melhor exemplo disso é a livre escolha entre alternativas. Essa liberdade só existe enquanto não faço a escolha. Uma vez que efetivei minha liberdade e escolhi, eu não a tenho mais. Se, por outro lado, fico na indecisão, minha liberdade permanece mera potencialidade, nunca se torna realidade.

Portanto, diz Hegel, essa liberdade de escolha, de tomar decisões, de exercer um poder, não pode ser a mais fundamental. Por essa razão, este tipo de liberdade não pode ser o fundamento último de legitimação da prática, seja ela individual ou política. Isso é importante, porque normalmente entendemos a democracia exatamente sob o paradigma da escolha entre opções diferentes. Nas 
eleições, sou confrontado com uma lista de partidos diferentes. Minha liberdade consiste em poder escolher um. Segundo Hegel é exatamente essa concepção de liberdade política e de participação no Estado que é insuficiente.

Mas qual seria, então, a liberdade verdadeira, a liberdade que não se esgota em sua efetivação, que não depende da subordinação e da alienação? Logicamente só pode haver uma forma de vontade que consegue isso. É aquela vontade livre que não está voltada ao diferente de si, mas a si mesma. Segundo Hegel, a vontade verdadeiramente livre é a vontade livre que quer a vontade livre. A liberdade originária consiste na vontade livre que tem a si mesma como conteúdo, objeto e fim. Só quando quero a mim mesmo enquanto livre, quando quero minha própria liberdade, eu de fato sou livre.

Mas com isso a concepção de liberdade, de vontade e conseqüentemente de prática muda totalmente. A vontade livre não é mais, em primeiro lugar, uma fonte originária de um agir, de um mudar e subjugar o mundo. Ela é, antes de qualquer coisa, uma fonte e uma forma originária de ser, de efetivar e formar sua própria existência. Liberdade é a efetivação de uma relação comigo mesmo. Ela é a prática do ser enquanto ente consciente, racional. Como tal ela é fundamentalmente uma prática do conhecer, do entender-se, do pensar-se e do saber-se. Ela é a compreensão originária e efetiva da própria existência. Cito o $§ 23$ dos "Princípios da Filosofia do Direito":

\footnotetext{
Somente nessa liberdade a vontade está consigo mesma, porque não se refere a outra coisa senão a si mesma. Com isso qualquer relação de dependência deixa de existir. - [Essa vontade] é verdadeira ou, melhor dizendo, ela é a própria verdade porque seu determinar consiste nisso que ela seja em seu ser-aí, i.e. naquilo em que ela está de frente a si mesma, idêntica a seu conceito. Nessa vontade, o conceito puro tem como finalidade e realidade a intuição de si mesmo.
}

\section{Liberdade como Existencial Social}

Essa concepção de liberdade de intuir-se e realizar-se enquanto sua própria verdade, enquanto verdade de seu ser-aí, eu chamaria de "existencial". A liberdade hegeliana é uma liberdade existencialista. Sua preocupação não é, em primeiro plano, com a escolha, a decisão ou com a negação de restrições. Ela é, antes de mais nada, uma forma de vida, um modo de executar sua própria existência sob uma auto-compreensão derterminada: a auto-compreensão de ser, essencialmente, livre. Os outros aspectos da liberdade que Hegel também reconhece apenas se seguem disso. Hegel retoma o antigo projeto platônico e aristotélico da teoria do "eu zen", i.e., da vida boa. Ele não quer mostrar apenas como se age de forma moralmente correta. Ele quer mostrar como se vive existencialmente bem. E isso se faz vivendo na auto-consciência da liberdade, em estruturas sociais (família, sociedade civil, estado) adequadas. 
A meu ver, é essa a preocupação fundamental da filosofia prática de Hegel, sobretudo em contrapartida à kantiana: Ele quer reconduzir a determinação da tarefa da filosofia prática àquela original de determinar a vida boa como um todo - e não reduzi-la a uma doutrina normativa de decisões ou ações particulares e de motivações para essas. I.e., Hegel critica a Moralidade kantiana não apenas com relação a seu conteúdo, mas com relação a sua forma fundamental: Essa, aos olhos de Hegel, é a forma errada - uma forma unilateral e mutilada - de fazer Filosofia Prática ou "Ética" (no sentido hegeliano, é claro). A alternativa hegeliana a essa Moralidade - que é a famosa "Eticidade" - portanto, não é apenas "Moralidade mais Intersubjetividade", uma "Ética das Estruturas Institucionais", p.ex. Ela é algo fundamentalmente diferente, um projeto "existencialista" de uma vida boa integral, uma teoria não apenas do dever, mas do "ser" no sentido da existência enquanto vivência individual e social. A Liberdade existencialista de Hegel é a Idéia (no sentido hegeliano) fundamental de uma vida, de uma vivência, não apenas como autodeterminação ou até somente como autonomia, mas como auto-realização ou "auto-ser" enquanto "auto-existência". É este o existencial de uma "espiritualidade da liberdade".

Vários filósofos acham que a preocupação fundamental de Hegel seja, diferentemente disso, com a reconciliação. Evidentemente Hegel trata muitas vezes da reconciliação. Mas em nenhum lugar este termo tem um papel central sistemático. Os termos centrais de Hegel são a Identidade (de identidade e não-identidade), a Verdade (como identidade de sujeito e objeto), o Saber Absoluto, a Idéia (como identidade de realidade/realização e conceito), o Espírito e outros conceitos de formas de auto-relacionamento identificador perfeito. A reconciliação permanece, em comparação a estes, num âmbito exterior, contingente, da identificação provisória e não perfeita, vaga e imperfeitamente sistematizada. Mesmo neste âmbito do histórico, a reconciliação, evidentemente, não pode ser senão um passo (portanto, o passo essencial) em direção ao estado perfeito de realização do Espírito neste âmbito, já que a reconciliação é um ato singular. A questão decisiva é o que vem depois, ou seja, qual é a realidade estável que se abre pela reconciliação e que, de antemão, precisa necessariamente ser a motivação e a orientação da reconciliação. Aí a resposta só pode ser: a vivência contínua da liberdade, i.e. a Eticidade. Enfatizar a reconciliação ao invés da liberdade e da Eticidade parece ser fruto do espírito liberalista, que enfatiza a decisão, o ato único e decisivo - que, portanto, nunca pode ser o essencial de minha existência, porque a existência como tal não é algo pontual, único, mas um Todo, concreto, inserido num todo maior, num Ser-no-mundo - seja este mundo natural ou social. Ao invés da ética "decisionista", Hegel não enfatiza a decisão, o salto, a conversão, a justificação pontual, o início do estado perfeito, enfim: a reconciliação - estes são apenas momentos, embora necessários, do processo dialético para chegar ao final. O essencial, para Hegel, é o resultado final: a "forma de vida vivida", a Eticidade, que é a liberdade como auto-reconhecimento, auto-efetivação e auto-realização plenas e contínuas do espírito.

O que eu chamo de "existencial" em Hegel é bem parecido, em vários aspectos, com o conceito da virtude em Aristóteles. Essa também é uma postura geral que faz parte da realização de 
uma vida boa, uma forma permanente de vivência. Porém, a virtude aristotélica se difere formalmente da liberdade Hegeliana, porque ela não é entendida (pelo menos não expressamente) como forma de efetivação reflexiva da própria existência. Além disso, as virtudes aristotélicas não são sistematizadas e, muito menos, resumidas numa única virtude, enquanto para Hegel, a liberdade na eticidade é a postura de vivência suprema que engloba todas as outras.

Mas em Hegel, como em Aristóteles, as ações e decisões - que para ambos não são o objeto primário da filosofia prática - se determinam naturalmente e sem um esforço especial a partir das virtudes ou, em nosso caso, a partir do existencial da liberdade. A liberdade não se realiza, essencialmente, em ações e em tomar decisões (isso sempre conduz ao "paradoxo da liberdade", insolúvel), mas na efetivação da própria existência - que, naturalmente, também implica ações e decisões, mas como consequências da postura ética geral. Portanto, o critério formal do exame dos motivos das ações, ou seja, de sua universabilidade, como em Kant, não pode ser senão um critério secundário, formal, da reflexão externa, que, portanto, sempre traz a marca da exterioridade à efetivação de minha liberdade, i.e. a marca da auto-alienação do sujeito (apenas) moral. Hegel não nega que o critério do Imperativo Categórico seja correto. Ele nega que ele seja necessário como princípio próprio, tanto no sentido teórico, normativo, quanto no sentido prático, pragmático. A universalização é efetivada a partir da e no interior da vontade livre que quer a vontade livre em sua individualidade, sua particularidade e sua universalidade - e não como princípio da mera universalização abstrata frente ao particular e individual.

Evidentemente o próprio Hegel não usou a palavra "existencial", mas acho que o termo capta muito bem a idéia fundamental de Hegel se observamos dois pontos. Primeiro, o existencial da liberdade hegeliana difere dos existenciais dos existencialistas do século passado porque a liberdade hegeliana não é algo irracional. Muito pelo contrário, ela é o auge da racionalidade. Seguindo Hegel, então, a própria razão pode ser "existencial". A segunda diferença em relação ao existencialismo moderno, e que é conseqüência da primeira, é que o existencial da liberdade não é algo particular. Muito pelo contrário, a vontade livre que a vontade livre quer é exatamente aquele princípio, que, seguindo Hegel, leva o indivíduo à intersubjetividade, à participação na família, na sociedade civil e no Estado. O homem é um animal social não em contraposição à sua liberdade, mas em virtude de sua liberdade.

Mas como é que o querer de minha própria liberdade me leva ao reconhecimento do outro? Não me levaria este querer, muito pelo contrário, a um egoísmo absoluto? Mais uma vez temos que lembrar a primazia do teórico sobre o prático, ou, melhor dizendo, a concepção da prática verdadeira como efetivação da verdade. Ao querer minha própria vontade livre, efetivo não apenas um ato prático. Antes disso e como base nisso, tenho que efetivar um ato teórico, um ato de conhecimento. Ou, para formular com mais exatidão: tenho que efetivar um ato teórico que em si mesmo já é prático, um conhecer que realiza não apenas um conhecimento, mas um reconhecimento. Evidentemente não posso querer a vontade livre se não sei o que é vontade livre. Sem a elucidação do conceito de 
liberdade essa vontade seria um impulso cego. Ela seria, no máximo, um sentimento de liberdade. Ora, uma vontade cega que nem sabe para onde está orientada certamente não pode ser livre. $\mathrm{O}$ esclarecimento de seu conteúdo, de seu objeto e de seu fim é certamente a base essencial para que uma vontade se torne livre. A liberdade plena só pode evidentemente efetivar-se na base de um reconhecimento pleno de seu objeto. Portanto, a vontade livre que a vontade livre quer só pode ser plena no esclarecimento pleno de si mesma, i.e. na autoconsciência plena. Desta forma, essa autoconsciência não pode permanecer no patamar de um auto-sentimento. Deve ser permeada pela razão e, por essa, ser levada ao patamar do conceito. Apenas no conceito da liberdade a vontade livre pode livremente querer a si mesma.

Mas o conceito de liberdade não é mais algo particular como uma sensação ou um sentimento. Um conceito sempre é algo universal. A reflexão racional da vontade livre por si mesma resulta, com necessidade lógica, na universalização de seu objeto. Eu necessariamente não posso mais querer a liberdade apenas como minha, particular. Eu a conheço necessariamente e com isso a reconheço como universal. Isso significa que, querendo verdadeiramente a vontade livre, quero a vontade livre de qualquer sujeito, não apenas a minha.

Com isso, o conceito da liberdade existencialista apresentado aqui aproxima-se do conceito do reconhecimento, que é central, p.ex., na interpretação da Filosofia do Direito de Hegel que Axel Honneth apresentou, sobretudo quando Honneth explica que esse reconhecimento se realiza em práticas da interação intersubjetivas, e não apenas num ato singular, universal e abstrato de reconhecer o outro, p.ex., enquanto sujeito moral, como em Kant. Mesmo assim, o reconhecimento me parece ser apenas um momento da Eticidade, i.e. da liberdade realizada. Ele é um momento essencial, pois a liberdade - tanto a liberdade do outro quanto a própria liberdade - precisa ser refletida, tanto na cognição quanto na volição. E o conhecimento da liberdade só pode ser efetuado plenamante enquanto re-conhecimemento. Mas, primeiramente, me parece importante que, em Hegel, o objeto do ato do reconhecimento sempre é, em última instância, a liberdade. A liberdade é o princípio material do reconhecimento. $\mathrm{O}$ conceito do reconhecimento permaneceria subdeterminado ou até vazio sem sua inserção no contexto conceitual da liberdade. Em segundo lugar, o reconhecimento parece articular apenas um momento essencial da liberdade, o momento cognitivo. O outro momento seria aquele do querer, i.e. a volição da liberdade: essa não apenas reconhece a si mesma, ela quer a si mesma. É essa a vontade de realizar sua liberdade em ações, no campo da eticidade: em sua família, em sua profissão, em suas corporações e em seu estado. Com isso, Hegel, de certa forma, retoma o imperativo fundamental de Fichte, que é simplesmente e antes de mais nada: Age! - Seja ativo, realize sua própria existência em atos. Hegel coloca este imperativo num contexto da socialidade, i.e. da Eticidade. Porém, o importante aqui é que a exigência ética não é apenas uma exigência de agir de certa forma, mas de agir mesmo. Isso o Imperativo Kantiano não explica, e isso também não parece ser expresso suficientemente quando se fala apenas em reconhecimento e não em liberdade que é realizada na Eticidade. Nessa liberdade efetivada na vivência ativa, o sujeito livre encontra 
sua satisfação, a perfeição de sua existência. Este aspecto também não parece ser suficientemente explicado pelo termo do reconhecimento.

Além dos momentos cognitivo e volitivo, a reflexividade destes dois momentos é central para o conceito hegeliano da liberdade: ela é liberdade que tem a si mesma como conteúdo, objeto e fim. Por isso, o reconhecimento é, em primeiro lugar, auto-reconhecimento. O reconhecimento dos outros se segue imediatamente deste auto-reconhecimento, quando o sujeito livre realiza que a compreensão conceitual de sua liberdade sempre implica também a liberdade como universal - e não apenas como particular sua. Portanto, querendo a si mesmo como livre, ele quer, automaticamente, a liberdade de todo ser livre. Este aspecto formal da reflexividade também parece permanecer menos claro quando a ética hegeliana é discutida preponderantemente sob o conceito do reconhecimento, e não da liberdade.

\section{Democracia, Direitos Básicos e Estado-Direito}

Neste ponto já podemos inferir uma primeira conseqüência para a questão da democracia. Se a democracia se legitima a partir da liberdade de seus membros e se liberdade fundamentalmente não pode ser outra coisa senão a vontade livre que quer a vontade livre, então a pré-condição do exercício legítimo do poder democrático é o reconhecimento e a proteção dessa liberdade em qualquer indivíduo. Um estado democrático que desrespeita os direitos básicos dos indivíduos perde sua legitimação, torna-se um estado antidemocrático porque perde sua própria liberdade. Uma vontade que quer a opressão, a escravidão ou a aniquilação de certos homens não é mais uma vontade que quer universalmente a vontade livre. E como ela perdeu, desta forma, sua própria liberdade, ela não pode ser mais reconhecida como vontade livre. Ela não pode ser mais reconhecida como base legitimadora de uma decisão democrática. O poder democrático não é assim restringido por um princípio exterior, mas por seu próprio princípio que é a liberdade. $\mathrm{O}$ argumento central não é tanto que, ferindo os direitos básicos dos indivíduos, o Estado está, por decisão democrática, fazendo algo errado. $\mathrm{O}$ argumento é que numa tal decisão, ele não é mais democrático, ele nem é mais Estado. E com isso perde qualquer legitimação.

É, então, no direito que o reconhecimento universal da liberdade se realiza e se concretiza num primeiro passo. A realidade objetiva da vontade livre que a vontade livre quer é o direito abstrato, o direito como tal, diz Hegel. Parte fundamental deste direito são os direitos que Hegel chama substanciais. Esses são inalienáveis, jamais podem ser revogados ou transferidos, nem pelo próprio indivíduo. Podemos identificar os direitos substanciais mais ou menos com aquilo que hoje em dia chamamos de direitos humanos. Estes não se fundam numa decisão democrática. Muito pelo contrário, a vontade política só pode estabelecer-se legitimamente a partir do reconhecimento destes direitos. Portanto, não cabe a um parlamento, uma constituinte ou um plebiscito decretá-los. 
Cabe apenas reconhecê-los.

Além destes direitos substanciais, diz Hegel, o direito abstrato garante aos indivíduos o direito de apropriação e, em seguida, os direitos de propriedade. Estes o Estado tem que proteger também. O Estado só pode existir enquanto Estado Direito. O Estado Direito não é ainda a condição plena para um Estado, mas é a pré-condição mínima. Qualquer Estado, para poder chamar-se assim e para legitimar-se, precisa respeitar e proteger os direitos individuais e garantir a igualdade dos cidadãos face ao direito. Isso implica, evidentemente, que o sistema jurídico de um Estado legítimo precisa funcionar e precisa ser justo. Se num Estado o julgamento de tribunais é influenciado por parcialidade, por suborno ou por outros fatores injustos não apenas o julgamento particular perde sua legitimidade mas o Estado como um todo perde parte de sua legitimação. O mesmo acontece se o funcionamento dos tribunais não está garantido, se, p.ex. o julgamento de um caso simples como um acidente demora anos e anos.

\section{Democracia e Moralidade}

O Estado Direito é a pré-condição primeira de um Estado livre e, portanto, de uma democracia verdadeira. Mas o princípio da liberdade verdadeira exige muito mais que isso. O próximo passo da realização da vontade livre que quer a vontade livre, a segunda exigência da efetivação da liberdade, segundo Hegel, é a Moralidade. A Moralidade é a interiorização da consciência do direito, a consciência da instalação do direito como efetivação da própria razão, i.e. a consciência da autonomia. E a conseqüência disso é que a Moralidade é a consciência da responsabilidade e, por último, do dever puro do tipo kantiano que se origina da autodeterminação da razão compreendida como universal. Pela Moralidade a pessoa jurídica, enquanto portadora e reconhecedora de direitos, torna-se juiz de suas próprias ações. Ela torna-se sujeito. O sujeito moral não reconhece apenas o direito como realidade. Ele efetiva essa realidade dentro de si. Com isso ele se torna, bem no sentido kantiano, seu próprio legislador. Hegel critica a moralidade primeiro porque nela o sujeito retira-se na interioridade. Na Moralidade o direito não é mais algo objetivo, não é mais uma realidade geral, intersubjetiva do espírito, mas uma construção subjetiva. Segundo, Hegel critica a Moralidade porque nela o indivíduo se faz a autoridade última e não reconhece nada que ele próprio não tenha reconhecido como moral. Desta forma, o sujeito perde qualquer vínculo com a objetividade da liberdade, i.e. com as estruturas de obrigação intersubjetivas e de reconhecimento que precedem qualquer liberdade individual porque são a base da efetivação da mesma. A Moralidade, diz Hegel, precisa ser superada ou, mais exatamente, suprassumida.

Mas apesar disso a Moralidade dá uma contribuição essencial ao desenvolvimento da realização da liberdade, e sua exigência quanto ao Estado permanece irrecusável. O sujeito tem o direito de poder tomar consciência das estruturas objetivas da liberdade, i.e. do direito positivo e 
da organização do Estado. Ele tem um direito à oportunidade de compreendê-los como racionais, i.e. como efetivações daquela vontade esclarecida que quer a si mesma como livre. O sujeito precisa num Estado livre ter pleno acesso às leis, ao funcionamento das instituições e ao trabalho do governo. O Estado racional é necessariamente um Estado transparente. E mais que isso, o sujeito tem o direito de poder entender-se como legislador das leis do Estado. Por isso, mesmo na visão hegeliana monarquista do Estado, deve existir uma participação dos membros de um Estado na legislação. Isso não é em razão de o direito depender do assentimento da maioria democrática para sua validade. O direito, como vimos, para Hegel, não se fundamenta na liberdade arbitrária dos indivíduos e no consenso ocasional deles, mas na universalidade e necessidade da razão no reconhecimento de sua liberdade enquanto geral. Mas com a participação dos sujeitos livres na legislação a efetivação da autodeterminação da vontade livre, que no direito abstrato foi abstrata, torna-se concreta e histórica.

Daí resultam mais precondições para a democracia. Como já dissemos, o Estado democrático deve ser um Estado transparente. O povo precisa poder compreender tanto as leis quanto a estruturas institucionais do Estado, precisa poder acompanhar os atos do governo e precisa poder compreender sua racionalidade. Há três problemas fundamentais quanto a este ponto. Primeiro, o Estado precisa garantir pelo menos um mínimo de educação para seus cidadãos para possibilitar tal compreensão. Segundo, ele precisa fornecer informações, de uma maneira objetiva - não daquele tipo de propaganda que elogia os atos do governo - e ele precisa abrir-se às investigações de um jornalismo crítico. Terceiro, o Estado não deve ofuscar a transparência de sua legislação e de sua organização através da complexidade. Este ponto talvez seja o mais difícil hoje em dia porque, evidentemente, a urbanização dos Estados modernos e seus códigos têm uma extensão que não permite mais fazê-los transparentes em todos os detalhes para quem não seja especialista. Mesmo assim, a inteligibilidade da realização da liberdade no Estado continua um desafio essencial dele mesmo. Sem essa inteligibilidade, a democracia automaticamente se torna uma "expertocracia" porque apenas os especialistas, os conhecedores do sistema, sabem como usá-lo.

Mas a Moralidade formula não apenas precondições de um Estado legítimo. Formula também a condição de uma cidadania legítima. Só se tivermos interiorizado o respeito pelo direito na Moralidade somos justificados para participar no Estado e exercer nossa liberdade nele. A democracia não existe para os indivíduos exercerem irrestritamente seu livre arbítrio. A liberdade que ela garante é a liberdade de sujeitos morais. Portanto, no exercício de meus direitos políticos ou no exercício de um cargo político não sou livre para seguir qualquer impulso. Sou livre apenas para seguir o impulso da razão à liberdade, o impulso da vontade livre à vontade livre. Minha decisão, seja como eleitor, seja como portador de um cargo político, seja em qualquer outra forma de participação no Estado, sempre deve ser uma decisão ética, nunca uma de preferências particulares, nem de preferências particulares da maioria. 


\section{Democracia e Eticidade - o "Patriotismo da Liberdade"}

A superação da Moralidade leva o homem a um patamar mais alto na efetivação de sua liberdade. Compreendendo que a moralidade é defeituosa por ser apenas subjetiva e por efetivar a liberdade apenas na interioridade, o sujeito se abre à realidade objetiva para nela buscar o que a mera interioridade não lhe forneceu. E lá ele facilmente encontra o que ele busca, porque nossa vida é cheia dessas realidades, ele até nasce de uma delas. Ao invés de construir abstratamente estruturas da Moralidade em seu interior, o homem se volta para o mundo em que vive e convive com outros, isto é, para o mundo social. E nele ele encontra todo um sistema de estruturas existentes, concretas, diferenciadas, institucionalizadas e vividas nas quais ele mesmo, desde sempre, está efetivando sua existência. E ao invés de submeter-se a um reconhecimento meramente formal de sujeitos teóricos morais, o homem que supera o estágio da Moralidade compreende que já está vivendo em relações de reconhecimentos específicos, pessoais, determinados. Ele compreende que desde sempre é um ente social. A convivência com os outros e as estruturas sociais não são produtos de sua Moralidade, não nascem de decisões de sua vontade livre. Muito pelo contrário, sua própria existência enquanto vontade livre nasce e se forma no seio dos laços sociais. A realidade da liberdade, i.e. a realidade do reconhecimento de si mesma da vontade livre não nasce de uma reflexão abstrata, vazia, mas do reconhecimento real, objetivo do outro. Apenas através da relação com o outro chego àquela relação comigo mesmo que constitui a liberdade verdadeira.

Segundo Hegel, essa relação se deu, nos estágios primordiais da história, na forma de uma luta pelo reconhecimento. A partir disso ela se desenvolveu, por muitos estágios intermediários, na direção daquela relação de reconhecimento mútuo geral que é ou pelo menos deve ser o fundamento do Estado moderno. Portanto, as estruturas de reconhecimento são concretas, históricas, ligadas a pessoas e comunidades específicas e com formas distintas, particulares.

Este âmbito do reconhecimento concreto e da liberdade objetivamente realizada Hegel chama de "eticidade". Nós a compreendemos melhor quando retornamos à distinção que fizemos no início. Se, em nossas primeiras reflexões sobre o conceito hegeliano da liberdade, chegamos a uma concepção de liberdade como existencial, como prática do autoconhecimento, i.e. do autoreconhecimento, na Moralidade, de certa forma, recaímos num conceito de liberdade entendido como tomar decisões e iniciar ações ou, pelo menos, de avaliar tais atos. Na eticidade, voltamos àquela concepção de liberdade como existencial, como forma de efetivar nossa existência enquanto espíritos racionais. Só que agora fazemos isso não apenas no reconhecimento de pessoas jurídicas com seus direitos pessoais, mas no reconhecimento de sujeitos éticos, aos quais somos relacionados por laços sociais. Estes laços e suas estruturas específicas constituem o espaço da efetivação verdadeira de nossa liberdade.

Essa eticidade, então, seria a terceira precondição da democracia. Ela organiza-se, segundo 
Hegel, em três âmbitos: a família, a sociedade civil e o estado.

\section{Democracia e Família}

O Estado fundamentado na liberdade pressupõe e exige que seus membros possam nascer e criar-se em relacionamentos de reconhecimento pessoal. Para possibilitar o desenvolvimento daquela vontade livre que quer a vontade livre a criança deve experimentar sua existência como bem-quista por outros. $\mathrm{O}$ amor familiar é essencial para a liberdade originária crescer num Estado. $\mathrm{O}$ amor, é, então o primeiro existencial da eticidade, a primeira concretização do existencial da liberdade enquanto plenamente realizada. $\mathrm{O}$ amor entre os casais e o amor entre pais e filhos têm uma função e um caráter não apenas particular, mas originariamente político. A família, não apenas por razões biológicas, mas por necessidade da liberdade é a raiz do Estado. Resta observar que com isso não nos fixamos num certo tipo de família. Hegel, evidentemente, pensava na família burguesa. Mas hoje em dia podemos perfeitamente imaginar estruturas diferentes conquanto que cumpram as exigências básicas: devem ser estruturas que, com um mínimo de estabilidade, sejam caracterizadas pela efetivação do amor, i.e. do querer o outro enquanto existência própria, e que, no caso das crianças, levem os indivíduos a desenvolver este relacionamento de reconhecimento em relação a si mesmo.

\section{Democracia e Sociedade Civil}

Hegel é o primeiro filósofo a compreender a importância da sociedade civil. Ela abrange todas aqueles relacionamentos e associações que os indivíduos estabelecem voluntariamente e por conta própria para satisfazer suas necessidades, sejam elas materiais, culturais ou religiosas. Estão incluídos nela todos os relacionamentos de trabalho, de produção e mercado, as corporações e associações profissionais. Para Hegel, ela abrange também o sistema judiciário e a polícia (num sentido bem mais amplo que entendemos hoje em dia, abrangendo a garantia de infra-estrutura, assistência social etc.). Mais uma vez Hegel vê a sociedade civil e seu bom funcionamento não apenas como condição externa do político, como um mero instrumento para satisfazer as exigências da população. A participação na sociedade civil já é, por si mesma, intimamente política, porque nela a convivência dos indivíduos é organizada em estruturas racionais que se baseiam num reconhecimento mútuo enquanto cidadãos livres. Os existenciais deste reconhecimento "civil" são o etos profissional junto com a honra profissional e a solidariedade.

Como Hegel pensou a sociedade civil já como política, como realização da liberdade, ele visava organizar a participação política no Estado a partir das estruturas comunitárias já estabelecidas 
nela. Os cidadãos deveriam exercer sua liberdade política não como indivíduos abstratos, atomísticos, como acontece nas eleições democráticas hoje em dia, mas como membros de corporações civis e por meio dessas corporações. Por várias razões, acho que devemos insistir contra Hegel no voto livre, igual e secreto que cada cidadão pode exercer sem consideração à sua posição na sociedade civil. Mas talvez seja propício hoje em dia re-introduzir nas democracias formas de participação através dos órgãos da sociedade civil também, como p.ex. a integração pelo menos consultiva de organizações não-governamentais, de associações profissionais como p.ex. a OAB e de associações de moradores e produtores p.ex. no modelo do orçamento participativo. Isso talvez possa ajudar a combater a tendência ao anonimato, desintegração e concorrência inerentes à democracia partidária e às eleições anônimas, gerais.

\section{Democracia e Estado}

Por último a liberdade, para Hegel, realiza-se no Estado. Aqui a universalidade da vontade livre que quer a vontade livre no reconhecimento intersubjetivo completa-se porque os indivíduos se reúnem numa vontade só, numa vontade livre geral do Estado como indivíduo próprio. O existencial da vivência livre, participativa no Estado é o patriotismo. Este não é o patriotismo no sentido de colocar bandeiras nacionais no tempo da copa, não é um sentimentalismo e nada que me permita sentir-me superior a outros povos. O patriotismo hegeliano é, antes de tudo, um patriotismo da liberdade, um existencial racional, esclarecido, da convivência responsável e identificadora numa união política, soberana.

O patriotismo é a concretização da liberdade. A liberdade precisa de uma pátria, de um lar, de uma comunidade solidária de reconhecimento mútuo para realizar-se como liberdade existencial. Essa pátria nós já temos porque não pode ser outra que aquela na qual nascemos, crescemos e na qual efetivamos nossa vivência cotidiana. Mas ao mesmo tempo, resta a nós construirmos essa pátria. Porque sabemos muito bem que em nossas pátrias atuais muitos não têm a chance de efetivar plenamente sua existência como sujeitos livres, e que, pior ainda, muitos são até ameaçados em sua própria existência, pela fome, pela pobreza e pela violência.

O patriotismo da liberdade seria, então, a precondição última e mais eminentemente política da democracia. A democracia nem pode funcionar nem pode ser justificada se a realidade do Estado não estiver fundamentada no patriotismo no sentido especificado. Uma democracia entendida apenas como um sistema de mediação de interesses particulares e não como projeto e efetivação de uma existência política comunitária, originária, não é fundamentada na concepção verdadeira da liberdade e, portanto, não representa um exercício da liberdade. Uma tal democracia não seria outra coisa que a disputa cega institucionalizada de egoísmos atomísticos. 


\section{Algumas conclusões pragmáticas concretas}

Que se segue disso? Tendo compreendido a tarefa do político como a efetivação da liberdade verdadeira que se realiza no reconhecimento mútuo e concreto, a democracia torna-se, então, antes de tudo, um projeto, uma tarefa contínua e uma forma existencial de efetivarmos nossa vida enquanto seres livres. A democracia não é tanto uma permissão, uma autorização a escolher o que queremos, não é uma carta branca para qualquer decisão política. Muito mais do que isso, a democracia é uma obrigação, um desafio. A democracia é a construção contínua da liberdade. Por isso, ela exige de todos nós um etos ou até uma espiritualidade da liberdade, que se realiza no amor, na solidariedade e no etos profissional, e, ultimamente, no patriotismo da liberdade. Desta forma o âmbito do político não é mais apenas uma esfera específica para tomar decisões mas um aspecto fundamental da efetivação de nossa própria existência. Somos seres políticos não apenas quando participamos no poder estatal, mas quando educamos nossos filhos, quando exercemos nossa profissão, quando cultivamos as artes, quando nos reunimos em associações e quando discutimos e avaliamos criticamente nossos governos e as estruturas de nossa sociedade. Tudo isso devemos apreciar, tanto em nós mesmos como em nossos compatriotas, como contribuição à realização da liberdade. Ao mesmo tempo isso nos leva a tomar consciência de nossa responsabilidade política em todos este atos. A democracia começa em casa. Ela continua no trabalho e na vida pública e somente é concluída e completada no Estado. Ela é conquistada pelo reconhecimento, é fundada na eticidade de cada um de nós.

Mas, evidentemente, há também conseqüências para o Estado e para aqueles que nele exercem um poder. Primeiro o Estado tem que respeitar tanto as esferas da família e da sociedade civil quanto a consciência subjetiva da moralidade e o Estado de Direito como originários e irredutíveis. Deve reconhecer seu direito próprio e originário e respeitá-los como efetivações originárias da liberdade. Ele deve aceitá-los e garanti-los como precondições do Estado, como precondições do político que, em si mesmos, já são políticos. Deve aceitá-los não apenas como precondições funcionais mas como, ao mesmo tempo, fundacionais ou justificacionais, porque ambos os aspetos coincidem necessariamente naquela liberdade que consiste na efetivação de sua própria existência. O Estado deve ao mesmo tempo considerar as outras esferas de sua responsabilidade política e direcioná-las ao seu cumprimento. Assim, p.ex., se a sociedade civil não cumpre sua tarefa de fornecer a todos seus membros o necessário para a satisfação de suas necessidades básicas e garantir-lhes uma vida digna, o Estado tem evidentemente que intervir. Dependendo da situação, ele pode ser obrigado a implementar medidas de assistência social ou até à realização de uma reforma radical das estruturas do trabalho e da propriedade. Uma democracia radicada na liberdade pode e deve tornar-se radical se a existência de seres livres está em questão. Por último, qualquer pessoa que exerce um poder político numa democracia, seja o povo nas eleições, sejam os políticos, sejam os governos, precisam lembrar que eles não têm um compromisso com o livre arbítrio de indivíduos desvinculados entre 
si, mas com a liberdade verdadeira de seres racionais, sociais e políticos, com a vontade livre que quer a vontade livre. Mesmo na democracia o voto não justifica qualquer coisa. Tanto o próprio eleitor como o eleito têm que justificar suas decisões, seu poder e sua existência diante do princípio último e fundamentado da democracia: a liberdade.

\section{Conclusão sistemática fundamental: a liberdade como princípio formal-material}

Hegel, tanto na ética como na filosofia política, não se contenta com um puro procedimento formal. Ele insiste que qualquer poder, qualquer Estado e qualquer membro de um Estado - mesmo se as estruturas procedimentais daquele Estado e daquela sociedade sejam as mais perfeitas que se possa imaginar - têm que obedecer a um princípio material. Ao mesmo tempo ele evita o grande perigo de um tal princípio ético-politico material: o perigo da violação da liberdade em nome do bem maior. Hegel nega que este princípio material possa ser um princípio metafísico (no sentido tradicional), natural (no sentido do jusnaturalismo tradicional), histórico positivo (como p.ex. no comunitarismo), antropológico, transcendental, consensual ou outro qualquer. O único princípio material legítimo é a própria liberdade: a liberdade real, realizada na vivência concreta, a liberdade enquanto existencial e espírito objetivo. Essa é a grande e genial reviravolta do pensamento político hegeliano.

Essa fundamentação da legitimação do Político no princípio da liberdade real como princípio tanto formal quanto material, ou seja, igualmente formal e material, precisa a meu ver ser aceita como precondição da democracia. A força normativa de um princípio apenas formal não é suficientemente forte para evitar que a democracia se perverta, que ela se volte contra a própria liberdade (como, p.ex., através do voto majoritário oprimir uma minoria, assaltar um outro Estado ou instalar uma ditadura). O princípio fundamental da Filosofia Prática hegeliana tem essa força normativa. Ele é suficientemente forte tanto para orientar decisões políticas democráticas quanto para avaliar estruturas existentes, mesmo nas democracias, e para justificar medidas até radicais em casos em que essas contradigam o princípio. Ao mesmo tempo Hegel evita que a força normativa do aspecto material desse princípio se volte contra a liberdade porque o princípio é a própria liberdade.

É interessante notar que, com o princípio formal-material ou "estrutural-existencial" da liberdade, Hegel chega a resgatar tanto as precondições fundacionais quanto as precondições funcionas que distinguimos no início. $\mathrm{O}$ desenvolvimento da liberdade realizada produz não apenas estruturas normativas. Também produz exatamente estas estruturas de reprodução biológica e social como também de produção econômica e cultural - junto com os subsistemas de educação, formação, ciência, arte, imprensa, opinião pública etc. - que uma democracia moderna precisa pressupor para seu bom funcionamento. Em Hegel, porém, essas estruturas não têm apenas um valor subsidiário, instrumental. Não são apenas necessidades funcionais. São realidades éticas próprias. 
Como, na filosofia hegeliana, o formal nunca pode ser separado do material, o procedimental nunca do substancial, a família e a sociedade civil têm seu valor originário em virtude da racionalidade de suas estruturas na satisfação das necessidades naturais e culturais. Enquanto tais "sistemas das necessidades" elas já são sistemas da liberdade, porque o espírito racional pode reconhecer sua própria racionalidade neles.

O princípio da liberdade como Hegel o entende parece ser, portanto, de fato aquele princípio - e o único princípio pensável - que permite não apenas usar ou conservar a liberdade, mas viver a liberdade, tanto enquanto indivíduo na sociedade quanto enquanto sociedade como um todo de indivíduos livres. Essa vivência da liberdade precisa ser o fim último e norteador da política. A realidade fundamental do Político, segundo Hegel, não é o poder, mas o viver: a existência comunitária, a convivência na liberdade. Portanto, as formas e sistemas da distribuição do poder se justificam somente diante dessa realidade. Eles precisam servir à liberdade, enquanto suas realizações institucionais. Assim, mesmo a Democracia como forma de distribuição do poder não pode ser um fim em si mesma. Ela tem que servir a algo maior e só se justifica pelo cumprimento deste serviço ao princípio mais alto de todo o Político: a realização da liberdade. 


\section{Referências}

HEGEL, G.W.F. Fenomenologia do Espírito [FdE] (trad. Paulo Meneses, Karl-Heiny Efken e José Nogueira Machado), Petrópolis ${ }^{4} 2007$.

HEGEL, G.W.F. Princípios da filosofia do direito [PFD] (trad. O. Vitorino), Lisboa 1990.

BUCHWALTER, A. Habermas, Hegel, and the Concept of Law, In.: R. Schomberg, K Baynes, ed., Discourse and Democracy: Essays on Habermas's Between Facts and Norms, New York 2002, 129-152.

HARDIMON, M. Hegel's Social Philosophy: The Project of Reconciliation, Cambridge 1994.

HONNETH, A. Leiden an Unbestimmtheit. Eine Reaktualisierung der Hegelschen Rechtsphilosophie, Stuttgart 2001.

NEUHOUSER, F. Foundations of Hegel's Social Theory: Actualizing Freedom, Cambridge (Mass.), London 2000.

PINKARD, T. Hegel's Phenomenology: The Sociality of Reason, Cambridge 1996.

RAWLS, J. Lectures on the History of Moral Philosophy, Cambridge (Mass.), London 2000.

ROSENFIELD, D. Politique et liberté. Structure logique de la Philosophie du droit de Hegel, Paris 1984.

UTZ, K. Liberdade em Hegel, In.: Veritas 50/2 (2004), 257-283. 